\title{
Chronic venous insufficiency symptoms and its potential causes: Are we doing it right?
}

\section{Síntomas de la insuficiencia venosa crónica y sus posibles causas. ¿Lo estamos haciendo bien?}

\author{
Enrique Santillán-Aguayo ${ }^{*}$, José de J. Rivera Sánchez², Verónica Carbajal-Robles \\ Javier Duarte-Acuña ${ }^{1}$, Felipe A. Piña-Avilés ${ }^{1}$, and Miriam V. Ramírez-Berumen ${ }^{1}$ \\ ${ }^{1}$ Angiology and Vascular Surgery Service; ${ }^{2}$ Research Department. Hospital General de México, Mexico City, Mexico
}

\begin{abstract}
Background: Chronic venous insufficiency has symptomatology associated with venous hypertension; until now they have never been approached for the purpose of describing a characteristic pattern presentation allowing a clinical differential diagnosis. The largest study addressing this topic is the Vein Restoration Study (VRS) that included 38,750 patients demonstrating discrepancy between signs and symptoms among age groups studied, coupled with the fact that in our own medical practice as a vascular specialist we may face patients with advanced degrees of venous hypertension but completely asymptomatic. Symptoms have been reported as subjective and potentially confoundable with other comorbidities such as neuropathies, as there is a close anatomic relationship between veins and nerves. Methods: Electronic literature searches were performed from 1947 to 2021 by the first author using PubMed and the Cochrane Central Register of Controlled Trials. Results: We found 1200 articles using those related to venous symptoms noting any of them focused on the pattern presentation with evident discrepancies between signs and symptoms. Conclusion: Venous symptoms must be considered subjective, and potentially caused by an underlying and undefined condition or comorbity. Until now, no author has demonstrated that these are caused directly by venous disease.
\end{abstract}

Key words: Venous symptoms. Chronic venous insufficiency. Venous hypertension.

\section{Resumen}

Introducción: La insuficiencia venosa tiene síntomas relacionados con hipertensión venosa, pero hasta ahora éstos no se han enfocado con el propósito de describir un patrón de presentación característico que permita establecer de forma clínica un diagnóstico diferencial. El estudio más grande Vein Restoration Study (VRS) que incluyó a 38,750 pacientes demostró una discrepancia de los síntomas y signos entre dos grupos etarios estudiados; en la práctica de los autores como especialistas vasculares es posible atender a un paciente con grados avanzados de hipertensión venosa pero asintomáticos. Los síntomas se han notificado como subjetivos y tal vez confundibles con los de otras anomalías comórbidas como las neuropatías, dado que existe una estrecha relación anatómica con los nervios. Métodos: Búsqueda electrónica de artículos en relación con síntomas venosos entre los años 1947 y 2021, por investigador principal, a través de PUBMED y Cochrane. Resultados: Se encontraron 1200 artículos y se utilizaron aquéllos vinculados con síntomas venosos, sin identificar alguno enfocado en el patrón de presentación esperado y con evidentes discrepancias entre signos y síntomas. Conclusión: Los síntomas venosos deben considerarse como subjetivos, y pueden ser causados por una comorbilidad subyacente y no identificada. Hasta ahora ningún autor ha demostrado que estos sean causados de forma directa por la enfermedad venosa.

Palabas clave: Síntomas venosos. Enfermedad venosa crónica. Hipertensión venosa.

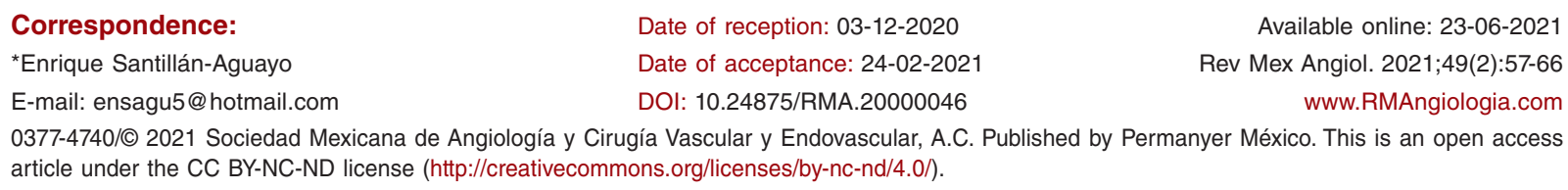

Date of reception: 03-12-2020

Date of acceptance: 24-02-2021

*Enrique Santillán-Aguayo

E-mail: ensagu5 @ hotmail.com

DOI: 10.24875/RMA.20000046

Available online: $23-06-2021$ Rev Mex Angiol. 2021;49(2):57-66 www.RMAngiologia.com

0377-4740/@ 2021 Sociedad Mexicana de Angiología y Cirugía Vascular y Endovascular, A.C. Published by Permanyer México. This is an open access article under the CC BY-NC-ND license (http://creativecommons.org/licenses/by-nc-nd/4.0/). 


\section{Introduction}

A book regarding the description and clinical characterization of the symptoms provoked by chronic venous insufficiency (CVI) was first published in 1964'. It is no surprise that anatomy and the initial comprehension of venous physiology but above all, its physiopathology was not concentrated by a vascular specialist (vascular surgeon, angiologist, or vascular medicine specialist) because the first workgroup created and identified in the world with medical and no surgical purposes was in $1991^{2}$ in Europe, emitting first recommendations for the specialty in $1993^{3}$. Arnoldi ${ }^{1}$, a recognized physician focused on the treatment of diverse orthopedic pathologies, was first in writing a 75 page and 15 chapter's book titled "The venous return from the lower leg in Health and CVI: A Synthesis" based on its own experience and observations on dynamic phlebography, collaboration among with Bauer, Barcroft, Burch, and Sodeman as well of the anatomic studies previously reported by Askar, Cockett, Dodd, Eger, and many other authors; 35 bibliographic references, published in different scientific medical journals.

Arnoldi, based on 307 patients to whom he made phlebography's, characterized five symptoms described in table 1. Arnoldi focused predominantly on bursting diffuse pain but considered all symptoms as subjective. He associated bursting pain mostly to anomalies of the deep venous system, and almost exclusively to extent deep valvular incompetence, either post-thrombotic syndrome (PTS) or as he referred idiopathically. About $17.9 \%(n=55)$ of the cohort studied without symptoms and as high as $42 \%(n=21)$ in Group la (only varicosities, normal venous pump, and no thrombosis) and $22 \%$ in Group Ila (impaired but functional venous pump with incompetent perforating veins compensating at some point with the superficial system) reporting themselves as asymptomatic, even though by severity, Group II had the higher venous hypertension with $50 \%$ of ulcers in Ila and $80 \%$ in Group Ilb".

All the authors as mentioned above have described different surgical techniques, some of them surprising attempts to achieve clinical improvement to patients with severe venous pathology as Bauer's reported technique resecting popliteal vein, treating what we know as PTS, and first-ever lineal venoplasty ${ }^{4}$, forerunner to mayor stripping studies realized by Boyd ${ }^{5}$. All of them had surgical training, and their contributions to our recent experience were a cornerstone. In America, a pioneer in understanding venous function was Seligman in $1956^{6}$ and its contribution to surgical technique in
$1963^{7}$. Trying to understand physiology, physiopathology, and a way to surgically treat venous disease, all of them described in their studies edema, color ochre discoloration, and sclerosis of the skin (described as induration) with the consequent development of stasis ulcer. The skin's sclerosis was subsequently considered a dermoepidermitis, identifying since 1969 eczema as a characteristic sign in these patients ${ }^{8}$. All of them considered nosologically signs, many of which were described, as well as new strategies for surgical treatment, reported based on experiences in areas as phlebology, allergology, topic dermatotherapy, and dermatosurgery ${ }^{9}$. Never characterized symptoms nor efforts were focused on determining potential comorbidities explaining such symptoms.

\section{Materials and methods}

Electronic literature searches were performed from 1947 to 2021 by the first author using PubMed and the Cochrane Central Register of Controlled Trials. The search strategy included "CVI" AND "symptoms" NOT "treatment;" "CVI" AND "symptoms;" "CVl” AND "symptoms pattern presentation," then, we manually search relevant articles missed by electronic searches, language limitation to English and Spanish. After identifying relevant titles, abstracts were revised by the author trying to select those related to venous symptoms and pattern presentation not finding a single one, thereby deciding to revise and concentrate those symptoms in a way allowing us to identify the expected pattern presentation, opening a previously closed subject on to understand venous symptoms better.

\section{Results}

There were found 1200 articles. Approximately between 1960 and 1990, all literature reported regarding signs and symptoms is not available online, only historical record; nonetheless, titles focus almost solely on signs provoked by venous stasis, along with different surgical approaches ${ }^{8-17}$. In most recent studies, few of them exclusively concentrate on symptoms, and as shown in table $2^{1,18-21}$, none of them report pattern presentation ${ }^{22-24}$.

The symptoms that patients with venous hypertension present have varied little over the years (Table 2) ${ }^{18,19,25,26}$. There are no reports in the literature regarding asymptomatic patients, regardless of the severity of the disease, including chronic ulceration. Some papers report generic symptoms like pain in different degrees. Others 
Table 1. Symptoms and signs reported by Arnoldi in its book, $1964^{1}$

\begin{tabular}{l} 
Records the subjective symptoms noted on the day of admittance in the various phlebographic groups, together with the number of \\
leg ulcers \\
\hline Symptoms
\end{tabular}

Table 2. Symptoms of venous hypertension reported by some authors in literature

\begin{tabular}{|c|c|c|c|c|c|c|c|}
\hline \multicolumn{8}{|c|}{ Prevalence of symptoms } \\
\hline \multicolumn{3}{|c|}{ Author/year } & \multicolumn{5}{|c|}{ Author/year } \\
\hline Arnoldi', 1964 (307) & Symptoms & Total & \multicolumn{2}{|c|}{ Marston $^{19}, 2010$, two sub-analysis } & Symptoms & \multicolumn{2}{|c|}{ Total } \\
\hline 55 & Without & $17.9 \%$ & \multirow{4}{*}{\multicolumn{2}{|c|}{$\begin{array}{l}\text { National venous screening } \\
\text { program }^{27}(2234)\end{array}$}} & Pain & \multicolumn{2}{|c|}{$77 \%$} \\
\hline \multirow[t]{2}{*}{160} & \multirow{2}{*}{$\begin{array}{l}\text { Heaviness and } \\
\text { tiredness }\end{array}$} & \multirow[t]{2}{*}{$52.1 \%$} & & & Mild & & \\
\hline & & & & & Moderate & \multicolumn{2}{|c|}{$29 \%$} \\
\hline 100 & Slight pain & $32.5 \%$ & & & Severe & \multicolumn{2}{|c|}{$19 \%$} \\
\hline 63 & Bursting pain & $20.5 \%$ & \multirow{4}{*}{\multicolumn{2}{|c|}{ The San Diego Study ${ }^{20}$ (2211) }} & Cramps & \multicolumn{2}{|c|}{$10-15 \%$} \\
\hline \multirow[t]{2}{*}{41} & \multirow{2}{*}{$\begin{array}{l}\text { Restless legs and } \\
\text { cramps }\end{array}$} & \multirow[t]{2}{*}{$13.3 \%$} & & & Heaviness & $10-15 \%$ & \\
\hline & & & & & Swelling & $10-15 \%$ & \\
\hline 139 & Ulcer & $45.2 \%$ & & & Pain & $<10 \%$ & \\
\hline \multirow[t]{2}{*}{ Duque $^{18}, 2005$ (100) } & \multirow[t]{2}{*}{ Symptoms } & \multirow[t]{2}{*}{ Total } & \multicolumn{2}{|c|}{ Vein Restoration Study²1, $2018(38,750)$} & Symptoms & \multicolumn{2}{|c|}{ Total } \\
\hline & & & $\begin{array}{c}\text { A } \\
<65 \mathrm{a} \\
27,536\end{array}$ & $\begin{array}{c}\text { B } \\
>65 a \\
11,214\end{array}$ & & $\begin{array}{c}A \\
<65 a\end{array}$ & $\begin{array}{c}\mathrm{B} \\
>65 \mathrm{a}\end{array}$ \\
\hline 66 & Itch & $66 \%$ & 4717 & 1485 & Aching & $17.1 \%$ & $13.2 \%$ \\
\hline 44 & Pain in itching area & $44 \%$ & 6718 & 2803 & Cramping & $24.3 \%$ & $24.9 \%$ \\
\hline 63 & Leg fatigue & $63 \%$ & 7348 & 2736 & Fatigue & $26.6 \%$ & $24.3 \%$ \\
\hline 62 & Leg pain & $62 \%$ & 8315 & 3005 & Heaviness & $30.1 \%$ & $26.7 \%$ \\
\hline 48 & Muscle aches & $48 \%$ & 2843 & 1097 & $\begin{array}{l}\text { Restless } \\
\text { legs }\end{array}$ & $10.3 \%$ & $9.7 \%$ \\
\hline 47 & Heaviness & $47 \%$ & 16,907 & 6159 & Pain & $61.3 \%$ & $54.9 \%$ \\
\hline 53 & Cramps & $53 \%$ & 6284 & 3300 & Swelling & $22.8 \%$ & $29.4 \%$ \\
\hline 74 & Burning sensation & $47 \%$ & 2063 & 624 & Burning & $7.4 \%$ & $5.5 \%$ \\
\hline & & & 1950 & 542 & Itching & $7 \%$ & $4.8 \%$ \\
\hline
\end{tabular}

focus on heaviness, tiredness, pain, and swelling indistinct to edema. Some are more precise at describing symptoms and signs, establishing a clear difference between swelling and edema but none of them focusing 
or even mentioning a symptom pattern presentation and differential diagnosis.

It should be noted from table 2, in the study reported by Duque, itching was the predominantly sign and focus of the study; 66 patients referred itching and $62 \%$ had presented it in the past 6 months, 95\% mostly during late-afternoon and night, $50 \%$ of whom even had sleeping troubles, $40 \%$ woke up during the night because of it, and $15 \%$ requiring sleep meds to achieve it. About $62 \%$ of patients said that itch was in the pretibial region, $45 \%$ posterior calf region, and $40 \%$ in the thigh with a symmetrical pattern in both legs in $64 \%$. By last, $44 \%$ of patients referred pain and $74 \%$ burning sensation in the same spot of itching, all of them characteristic neuropathy symptoms, with no correlation between symptoms and severity of the disease, authors concluding according to observations that symptoms despite no correlation with severity, it does with chronic venous disease ${ }^{18}$.

In a revision published by Marston ${ }^{19}$ from a sub analysis of "National venous screening program" $(\text { NVSP) })^{27}$ and "San Diego Population Study" (SDPS) ${ }^{20}$, the results contrast regarding pain, reported as high as $77 \%$ in NVSP and $10-15 \%$ in SDPS; author concluded that although pain is the most predominantly symptom, none of the symptoms referred are specific for the disease, and multiple other diseases may be confused with venous insufficiency. Noting that neither of the two studies described symptoms in the text nor presented frequency, only signs or QoL questionnaires. In "Vein Restoration Study" (VRS) ${ }^{21}$, one of the largest, included prospective and retrospectively 38,750 patients in two main groups, those aged more than 65 years and those aged $<65$ years with a significant statistical difference between groups in symptoms and signs. Those aged $<65$ years had more frequent pain $(61.3 \%$ vs. $54.9 \%)$, fatigue $(26.6 \%$ vs. $23.4 \%)$, heaviness $(30.1 \%$ vs. $23.7 \%)$, and aching $(17.2 \%$ vs. $13.2 \%) p<0.0001$ (Tables 2 and 3 ), but higher rates of signs in those aged more than 65 years such as swelling ( $29 \%$ vs. $23 \%)$, skin changes $(12 \%$ vs. $6 \%$ ), hyperpigmentation ( $8 \%$ vs. $4 \%$ ), edema ( $55 \%$ vs. $43 \%$ ), and ulcer ( $5 \%$ vs. $2 \%$ ) $p<0.0001$ (Table 3), with no significant difference between cramping (25\% vs. $24 \%$ ) and restless legs (10\% vs. $10 \%$ ). Thus, it is necessary to do further studies explaining why, even though patients aged more than 65 years old presented more signs, they had fewer symptoms with strong statistical significance.
Table 3. Signs and symptoms reported in "Vein Restoration Study"21

\begin{tabular}{|c|c|c|c|}
\hline & 2015 & 2016 & Total \\
\hline $\begin{array}{l}\text { Age } \\
<65 \text { years } \\
>65 \text { years }\end{array}$ & $\begin{array}{c}11,252 \\
4409\end{array}$ & $\begin{array}{c}16,284 \\
6805\end{array}$ & $\begin{array}{l}27,356 \\
11,214\end{array}$ \\
\hline $\begin{array}{l}\text { Gender } \\
\text { Women } \\
\text { Men }\end{array}$ & $\begin{array}{c}12,204 \\
3450\end{array}$ & $\begin{array}{c}17,980 \\
5100\end{array}$ & $\begin{array}{c}30,184 \\
8550\end{array}$ \\
\hline Presenting symptoms & $\begin{array}{c}<65 \text { years } \\
\text { No. }(\%)\end{array}$ & $\begin{array}{c}>65 \text { years } \\
\text { No. }(\%)\end{array}$ & p value \\
\hline Aching & 4714 (17) & $1485(13)$ & $<0.0001$ \\
\hline Bleeding & $417(2)$ & $210(2)$ & $<0.01$ \\
\hline Cramping & $6718(24)$ & $2803(25)$ & $<0.21$ \\
\hline Fatigue & $7348(27)$ & $2736(24)$ & $<0.0001$ \\
\hline Heaviness & $8315(30)$ & 3005 (27) & $<0.0001$ \\
\hline Pain & $16,907(61)$ & $6159(55)$ & $<0.0001$ \\
\hline Restless legs & $2843(10)$ & $1097(10)$ & $<0.11$ \\
\hline Skin changes & $1539(6)$ & $1290(12)$ & $<0.0001$ \\
\hline Spider veins & 4625 (17) & 1367 (12) & $<0.0001$ \\
\hline Swelling & $6284(23)$ & $3300(29)$ & $<0.0001$ \\
\hline Thrombosis & $1189(4)$ & 304 (3) & $<0.0001$ \\
\hline Ulcer & $576(2)$ & $542(5)$ & $<0.0001$ \\
\hline Varicosities & $1607(6)$ & $567(5)$ & $<0.02$ \\
\hline $\begin{array}{l}\text { Associated symptoms } \\
\text { Burning } \\
\text { Dermatitis } \\
\text { Edema or swelling } \\
\text { Hyperpigmentation } \\
\text { Itching } \\
\text { Pelvic symptoms } \\
\text { Skin ulceration } \\
\text { Superficial } \\
\text { thrombophlebitis } \\
\text { Tingling }\end{array}$ & $\begin{array}{c}2063(7) \\
171(1) \\
11,872(43) \\
1159(4) \\
1950(7) \\
199(1) \\
332(1) \\
206(1)\end{array}$ & $\begin{array}{c}624(6) \\
137(1) \\
6155(55) \\
925(8) \\
542(5) \\
22(0) \\
130(1) \\
84(1)\end{array}$ & $\begin{array}{l}<0.0001 \\
<0.0001 \\
<0.0001 \\
<0.0001 \\
<0.0001 \\
<0.0001 \\
<0.718 \\
>0.99\end{array}$ \\
\hline
\end{tabular}

\section{Discussion}

Today, we understand that venous pathology, either primary or secondary, has important mechanical implications as, in the first place, the unidirectional valve function, which works as cardiac valves, through dynamic gradient pressure. Veins, unlike cardiac valves, are considered capacitance vessels, meaning their distensibility is high. They work along with muscles function in the calf against hydrostatic pressure. Unlike the myocardium, veins are not autonomic. They depend directly proportional to muscular trophic and tropism, physical 
activities, and movements in the hip, knee but mostly ankle, even mobility in metatarsophalangeal joints, so any pathologic condition targeting those previously mentioned may provoke muscular venous pump dysfunction, venous stasis, and its consequences.

Signs of venous disease are secondary to venous hypertension and are fully elucidated and include dilation of capacitance vessels until the formation of varix of different degrees, paths, and thickness, the presence of skin discoloration such as blanche atrophy and ochre color and induration now known as dermatoliposclerosis, edema, eczema, and as maximal consequence ulceration, which frequently is chronic and relapsing, mostly in perimalleolar territory, but atypical locations too as calf, toes, or sole. On the contrary, venous symptoms had been transcribed article by article, book by the book based on the observational results in 307 patients, and as the same Arnoldi mentioned, totally subjective. Those symptoms, even nowadays, are subjective in the validated quality of life (QoL) questionnaires, such as SF-36 and Euro-QoL DF and specific for the disease like CIVIQ-2. They are validated on precisely these subjective symptoms (mostly pain). CIVIQ-2 was presented in 1996 and translated into many languages and includes pain in the past weeks (without any specification), physical, social, and psychological repercussions in daily activities. Many authors use these questionnaires based on subjective symptoms as a guide to evaluating surgical, therapeutic compression, and pharmacological outcomes ${ }^{28-30}$.

Returning to previous stipulated conceptions by Arnoldi, where symptoms referred by patients were subjective and by Marston assuming multiple etiologies can produce similar symptoms, open, diverse investigation questions to answer to comprehend symptoms better.

\section{Symptomatic differential diagnosis}

\section{EDEMA}

First of all, it would be essential to establish a pattern presentation of symptoms associated with venous insufficiency; based on our physiological and physiopathological knowledge, whose we comprehended better than Arnoldi, Bauer, and Barcroft ${ }^{31,32}$. The venous pump has a $65 \%$ ejection fraction approximately, calculated by indirect means (plethysmography), to favor venous return against the column of hydrostatic pressure from ankles to the right atrium, going around $100 \mathrm{mmHg}$ in the erect position and $<30 \mathrm{mmHg}$ after 12 dorsiflexions of ankle's foot ${ }^{33-38}$. We also know in
Table 4. Etiology of edema of the leg by Dale in $1973^{15}$

\begin{tabular}{|l|l|}
\hline General & Lymphatic \\
\hline Hepatic cirrhosis & Primary lymphedema \\
\hline Heart failure & Congenital \\
\hline Nephrosis & Praecox \\
\hline Hypoproteinemia & Tarda \\
\hline Allergic disorders & $\begin{array}{l}\text { Acquired secondary } \\
\text { edema }\end{array}$ \\
\hline Idiopathic cyclic edema & Infection \\
\hline Venous & Filaria \\
\hline Thrombosis acute & $\begin{array}{l}\text { Lymphogranuloma } \\
\text { venereum }\end{array}$ \\
\hline Chronic post-phlebitic syndrome & Tuberculosis \\
\hline Extrinsic pressure & Syphilis \\
\hline Tumor & Tumor \\
\hline Retroperitoneal fibrosis & Post-radiation \\
\hline Pressure of overlying iliac artery & Post-operative \\
\hline Interruption & Toxic \\
\hline Trauma & Snakebite \\
\hline Surgical & Insect bite \\
\hline Arteriovenous fistula & Miscellaneous \\
\hline & Infectious \\
\hline Inflammation after \\
vascular repair
\end{tabular}

supine position hydrostatic pressure in every point measured turns equal; thus, we assume that venous edema (or symptoms) must never be present at rest while favoring gravitational potential energy, and not only improve but also disappear after some minutes of leg elevation, and above all in early disease stages.

Edema is studied since the eighties and caused by many diseases, initially by Andrew Dale ${ }^{15}$ in a text of 66 pages. It laid the foundations for actual etiological classification (Table 4), which required modifications based on physiopathologic mechanisms better defined. Including increased hydrostatic pressure, increased capillary permeability, lymphatic obstruction, hypoalbuminemia, hypercoagulability, refeeding edema (fasting, sodium retaining), and drug induced ${ }^{39}$, thus modifying Dale's table based on physiopathologic mechanisms to our current knowledge would be as table $5^{40,41}$. 
This comprehension leads us to affirm that venous edema is caused firstly, by increased hydrostatic pressure in acute illness, plus to the increased capillary permeability in its chronic form, and finally by the potential neurogenic role reported by Napier ${ }^{42}$. In patients with joint movement limitation by any reason, either neurogenic or even without neuropathy secondary to inappropriate muscular contractions, which may be caused by multiple reasons not necessarily neuropathic, rarely studied. However, without considering this last precept, acute venous edema must have a characteristic pattern presentation caused by increased hydrostatic pressure, different from the causes presented in table 5.

Given the fact that it is caused mostly by standing postures and less intense during sitting positions ${ }^{43}$, not abolished by the effects of gravitational potential energy during walking, exerted mechanically (but not exclusively) by venous valves ${ }^{44}$, absent in patients with valvular dysfunction. Therefore, edema must disappear during leg elevation for some minutes and mainly during absolute rest, exacerbated during walking directly proportional to activity, repeating this pattern day after day, never present at mornings in early stages (Table 6).

In the context of chronic venous disease, when venous hypertension is constant, and the valve extent damage is vast and involves numerous valves, plus the increased hydrostatic pressure and intrinsic relationship with that column of blood with capillaries, factors are added that contribute to the increase of vascular permeability. Leukocyte trapping (adhesion and migration of macrophage's, T lymphocytes, and mast cells), pro-inflammatory cytokines (select in, ICAM-1, ELAM-1, VCAM-1, VEGF, and TGF- $\beta 1$ ), and the role of pressure and shear stress when inverted promoting inflammation and reactive free radical formation had been identified as contributing factors ${ }^{45-47}$. Under this condition, edema may, accordingly to severity, be present in the morning, less in patients with thin skin trophic changes (or without it) and more in patients with profound skin sclerosis and atrophy blanche, but above all in those with eczema and ulcer; not excluding foot, fingers, or only be present in ankle or shin.

We should avoid confounding edema with venous swelling, which depends directly on venous volume in muscular veins such as soleus and gastrocnemius plexuses in the calf, considered the venous bellows in the leg; when present, there will not be Godette sign during digit pressure because the excess of volume will be in the intravascular compartment but not in the interstitial
Table 5. Etiologic classification of edema of leg by Dale modified by our current concepts ${ }^{15,39-42}$

\begin{tabular}{|c|c|}
\hline Increased hydrostatic pressure & Lymphatic, primary \\
\hline Hepatic cirrhosis & Primary \\
\hline Cardiac failure & Congenital \\
\hline $\begin{array}{l}\text { Acute and chronic renal } \\
\text { disease }\end{array}$ & Praecox \\
\hline Venous insufficiency & Tarda \\
\hline Arteriovenous fistula & Musculoskeletal \\
\hline Arterial and venous anomalies & Ruptured Baker's cyst \\
\hline Arteriovenous malformations & $\begin{array}{l}\text { Ruptured medial head of } \\
\text { gastrocnemius }\end{array}$ \\
\hline $\begin{array}{l}\text { May-Thurner syndrome, pelvic } \\
\text { congestion }\end{array}$ & $\begin{array}{l}\text { Compartment syndrome, } \\
\text { muscular infarct }\end{array}$ \\
\hline Acute venous thrombosis & $\begin{array}{l}\text { Neurogenic, reflex } \\
\text { sympathetic dystrophy }\end{array}$ \\
\hline Post-thrombotic syndrome & Lymphatic, secondary \\
\hline $\begin{array}{l}\text { Lymphatic extrinsic } \\
\text { compression }\end{array}$ & Infection sequelae \\
\hline Tumor & Filaria \\
\hline \multirow[t]{2}{*}{ Retroperitoneal fibrosis } & $\begin{array}{l}\text { Lymphogranuloma } \\
\text { venereum }\end{array}$ \\
\hline & Tuberculosis \\
\hline Hypoalbuminemia & Syphilis \\
\hline Protein-losing enteropathy & Post-radiation \\
\hline Malnutrition & Post-operative \\
\hline $\begin{array}{l}\text { Liver disease, nephrotic } \\
\text { syndrome, preeclampsia }\end{array}$ & Drug induced \\
\hline $\begin{array}{l}\text { Increased capillary } \\
\text { permeability }\end{array}$ & Opioids \\
\hline $\begin{array}{l}\text { Acute and chronic bacterial } \\
\text { infections }\end{array}$ & $\begin{array}{l}\text { Antihypertensives (+ channel } \\
\text { calcium blockers) }\end{array}$ \\
\hline After vascular repair & NSAID \\
\hline Snakebite & $\begin{array}{l}\text { Hormones: corticosteroids, } \\
\text { estrogen, testosterone }\end{array}$ \\
\hline Insect bite & Pioglitazone, rosiglitazone \\
\hline Chronic venous edema, mix & $\begin{array}{l}\text { Monoamine oxidase } \\
\text { inhibitors }\end{array}$ \\
\hline Allergic reactions, myxedema & Other \\
\hline Post-traumatic & Sickle cell crisis \\
\hline Rheumatic & Idiopathic \\
\hline Inflammatory myopathy, myositis & Refeeding edema, obesity \\
\hline Fasciitis & \\
\hline
\end{tabular}


Table 6. Pattern presentation of edema caused by increased hydrostatic pressure

\begin{tabular}{|c|c|c|c|c|c|c|}
\hline Disease & Contributing factors & Edema pattern & $\begin{array}{l}\text { Increase } \\
\text { during } \\
\text { walking }\end{array}$ & $\begin{array}{l}\text { Improve } \\
\text { during leg } \\
\text { elevation }\end{array}$ & $\begin{array}{l}\text { Improve } \\
\text { with } \\
\text { diuretic }\end{array}$ & Swelling \\
\hline Hepatic cirrhosis & $\begin{array}{l}\text { Hypoproteinemia } \\
\text { Right cardiac failure } \\
\text { Portal hypertension } \\
\text { Total blood volume } \\
\text { Pulmonary hydrostatic } \\
\text { pressure }\end{array}$ & $\begin{array}{l}\text { Supine } \\
\text { Mild: Absent in mornings } \\
\text { Moderate: Mildly present in } \\
\text { mornings } \\
\text { Severe: During all day }\end{array}$ & $\begin{array}{l}\text { Yes } \\
\text { Yes } \\
\text { Yes }\end{array}$ & $\begin{array}{l}\text { Yes } \\
\text { No } \\
\text { No }\end{array}$ & Yes & \\
\hline Cardiac failure & $\begin{array}{l}\text { Total blood volume } \\
\text { Vascular tone } \\
\text { Pulmonary hydrostatic } \\
\text { pressure }\end{array}$ & $\begin{array}{l}\text { Bimalleolar/All foot } \\
\text { Mild: Absent in mornings } \\
\text { Moderate: Mildly present in } \\
\text { mornings }\end{array}$ & $\begin{array}{l}\text { No } \\
\text { Yes }\end{array}$ & $\begin{array}{l}\text { Yes } \\
\text { No }\end{array}$ & $\begin{array}{l}\text { Yes } \\
\text { Yes }\end{array}$ & No \\
\hline $\begin{array}{l}\text { Renal } \\
\text { insufficiency }\end{array}$ & Total blood volume & $\begin{array}{l}\text { Severe: During all day, } \\
\text { including at waking up }\end{array}$ & Yes & No & No & \\
\hline $\begin{array}{l}\text { Chronic venous } \\
\text { disease }\end{array}$ & $\begin{array}{l}\text { Valvular disfunction } \\
\text { Increased local blood } \\
\text { volume }\end{array}$ & $\begin{array}{l}\text { Mild: Absent in supine and in } \\
\text { morning, it appears hours }\end{array}$ & $\begin{array}{l}\text { Yes / } \\
\text { Afternoon }\end{array}$ & Always & & No \\
\hline $\begin{array}{l}\text { Venous } \\
\text { malformation }\end{array}$ & & $\begin{array}{l}\text { including anterior foot and } \\
\text { toes }\end{array}$ & & & & \\
\hline & Increased permeability & $\begin{array}{l}\text { Moderate: Same } \\
\text { characteristics, from middle } \\
\text { third leg to the foot including }\end{array}$ & $\begin{array}{l}\text { Yes / Morning } \\
\text { or Late } \\
\text { morning }\end{array}$ & Yes & No & No \\
\hline $\begin{array}{l}\text { Posthrombotic } \\
\text { syndrome }\end{array}$ & $\begin{array}{l}\text { Valvular disfunction } \\
\text { Increased local blood } \\
\text { volume } \\
\text { Return obstruction }\end{array}$ & $\begin{array}{l}\text { usually associated to mild } \\
\text { skin changes } \\
\text { Severe: All leg, from calf and } \\
\text { down, with swelling, usually } \\
\text { associated to severe skin } \\
\text { changes, atrophy blanche or } \\
\text { eczema }\end{array}$ & $\begin{array}{l}\text { Yes / May be } \\
\text { present in } \\
\text { morning }\end{array}$ & $\begin{array}{l}\text { Yes, may } \\
\text { not } \\
\text { improve }\end{array}$ & & Yes \\
\hline $\begin{array}{l}\text { Arteriovenous } \\
\text { fistula }\end{array}$ & $\begin{array}{l}\text { Increased arterial flow } \\
\text { Vascular tone }\end{array}$ & $\begin{array}{l}\text { Schöbinger: } \\
1 \text { No edema or mild } \\
2 \text { Mild edema or absent, } \\
\text { constant }\end{array}$ & $\begin{array}{l}\text { May } \\
\text { Yes }\end{array}$ & $\begin{array}{l}\text { Yes } \\
\text { No }\end{array}$ & & $\begin{array}{l}\text { No } \\
\text { Yes }\end{array}$ \\
\hline $\begin{array}{l}\text { Arteriovenous } \\
\text { malformations }\end{array}$ & $\begin{array}{l}\text { Increased permeability } \\
\text { Increased local blood } \\
\text { volume } \\
\text { Valvular disfunction }\end{array}$ & $\begin{array}{l}3 \text { Moderate edema, constant } \\
4 \text { Cardiac failure pattern, } \\
\text { constant }\end{array}$ & $\begin{array}{l}\text { Yes } \\
\text { Yes }\end{array}$ & $\begin{array}{l}\text { No } \\
\text { No }\end{array}$ & 700 & $\begin{array}{l}\text { Yes } \\
\text { Yes }\end{array}$ \\
\hline $\begin{array}{l}\text { Arterial } \\
\text { malformations }\end{array}$ & $\begin{array}{l}\text { Vascular tone } \\
\text { Increased local blood } \\
\text { volume }\end{array}$ & & & & & \\
\hline $\begin{array}{l}\text { May-Thurner } \\
\text { syndrome, pelvic } \\
\text { congestion }\end{array}$ & $\begin{array}{l}\text { Return obstruction } \\
\text { Valvular disfunction }\end{array}$ & \multirow{2}{*}{$\begin{array}{l}\text { Mild: Absent in supine and } \\
\text { absent in mornings, few } \\
\text { patients } \\
\text { Moderate: May be present in } \\
\text { mornings, swelling may be } \\
\text { present in mornings too or } \\
\text { initiate during walking } \\
\text { Severe: Present in mornings } \\
\text { with swelling all day }\end{array}$} & Yes & Yes & \multirow[b]{2}{*}{ No } & No \\
\hline $\begin{array}{l}\text { Acute venous } \\
\text { thrombosis }\end{array}$ & $\begin{array}{l}\text { Return obstruction } \\
\text { Increased local blood } \\
\text { volume }\end{array}$ & & Yes & Mild & & Yes \\
\hline
\end{tabular}

In all cases, to a greater or lesser degree, contribute increased hydrostatic pressure (46) and all of improve with compression; venous etiology tends to improve significantly with compression. 
compartment. Nonetheless, they are frequently confused. Along Godette's sign absence, we will observe venous dilation, increased in leg perimetry, and muscular tension, which we most differentiate from muscular contracture.

\section{Pruritus and burning pain}

Itching is a symptom present in multiple potential etiologies, since dermatologic as inflammatory, infectious dermatoses, autoimmune, genodermatoses, dermatoses of pregnancy, and cutaneous neoplasms. Systemic diseases are associated with endocrine, metabolic, infectious, hematological and lymphoproliferative diseases, visceral neoplasms, pregnancy and drug-induced pruritus, and even associated with neurologic and psychiatric disorders such as neurogenic (without nerve damage), neuropathic (nerve damage), psychosomatic disorders, mixed, and even idiopathic ${ }^{48}$. All of them are poorly studied and understood, with some authors reporting contradictory results ${ }^{49}$. It is important to note that the paper from the International Forum for the Study of Itch does not mention to venous disease as a cause, although many authors in literature does. We may think that it is included and grouped among inflammatory groups. On the contrary, a complete table for those associated with neurogenic or neuropathic etiology. We must not forget itching is considered as a minimal pain expression.

Trying to associate itching with venous disease, remembering the current role of mast cell degranulation secondary to leukocyte entrapment ${ }^{45}$, may explain why in advance disease with eczema and ulcer patients frequently, although not all of them, refer it. A study by Paul ${ }^{50}$ found a correlation between disease severity and itching of $0.26 p=0.025$, not strictly linear because itch increased with the skin changes (CEAP 4 and 5$)$ ( $n=$ $33,44.5 \%$ ), but not necessary with the presence of an ulcer $(n=5,6.8 \%)$. A study by Paul ${ }^{49}$ found a correlation between disease severity and itching of $0.26 p=0.025$, not strictly linear because itch increased with the skin changes (CEAP 4 and 5$)(n=33,44.5 \%)$, but not necessarily with the presence of an ulcer $(n=5,6.8 \%)$, coupled with the fact that up to $54.7 \%$ of patients had an itch in many parts of their bodies, $45.9 \%$ of them specifically in legs. Some of them associate itch to a burning sensation in the same spot as Duque described $^{18}$ both characteristic symptoms of neuropathies.

\section{Tiredness, heaviness, and pain}

These three symptoms are dominant in chronic venous disease symptoms, as proven in VRS ${ }^{21}$. As far as now, there is no author capable of explaining physiopathological mechanisms on those symptoms. We could assume that heaviness and tiredness are associated with increased venous volume, thus as edema present during standing position and exacerbated during walking hours, relieving leg elevation within the $1^{\text {st }} \mathrm{min}$, and never being present at waking up or early in mornings. Because no author concentrates on pattern presentation of these symptoms in venous disease, we must still consider them as subjective. Arnoldi ${ }^{1}$ stated that intense (bursting) pain, which was intense enough for some of them to consider amputation, were exclusively present in those with important deep vein damage, associated with the practically constant high pressure in the deep veins of the leg, emphasizing it was never met in patients with simple varicose veins. It is important to remember again that in Arnoldi's study existed an asymptomatic group ( $n=55,19.7 \%$ ) with no other author or study group considering it as a study variable and the many potential causes explaining leg pain such as musculoskeletal or soft-tissue diseases.

\section{Cramps and restless legs}

Cramps and lack of strength are commonly associated with musculoskeletal diseases. There is no physiopathological mechanism explaining the presence of cramps and restless legs in CVI. Thus again, resorting to conjectures, assuming that because of venous congestion (swelling), muscles in calf in an attempt to counteract increased hydrostatic pressure provoke involuntary contractions, nonetheless, those contractions must not be severe or incapacitating or derive in residual muscular contractures, and never be present during night rest. On the other hand, restless legs should not be present during night rest as well considering venous hypertension is absent, thus, until now it is still necessary to make more studies focused in understanding exactly why these patients refer specific types of symptoms.

\section{Conclusion}

We may have taken the wrong direction in understanding venous disease symptoms because there is no symptomatic correlation, even though it exists for 
signs $^{21}$. New studies are necessary considering the potential role of the anatomic relationship between veins and nerves, described by many authors in other medical areas, trying to rule out causality, but never casualty ${ }^{51-55}$. Comorbid pathologies to consider are peripheral neuropathy (26-54\%) $)^{56-57}$ and underdiagnosed low back pain associated with radiculopathy ${ }^{58,59}$, as herniation incidence has been reported similar between low back pain and radiculopathy ${ }^{60-62}$, with a higher prevalence in younger patients ${ }^{59,63}$.

There may be other contributing factors to consider such as leg shortness ${ }^{64}$, history of trauma, and even microtraumas associated with daily life activities, against we know spinal hygiene. We must not forget that nerves are known as "the great simulators of the body" because they can simulate when damaged syndromes $^{65,66}$ or minor symptoms such as itching or cough $^{67}$.

\section{Funding}

This research has not received any specific grant from agencies in the public, commercial, or non-profit sectors.

\section{Conflicts of interest}

The authors declare no conflicts of interest.

\section{Ethical disclosures}

Protection of people and animals. The authors declare that no experiments were performed on humans or animals for this research.

Confidentiality of the data. The authors declare that no patient data appear in this article.

Right to privacy and informed consent. The authors declare that no patient data appear in this article.

\section{References}

1. Arnoldi CC. The venous return from the lower leg in health and in chronic venous insufficiency. A synthesis. Acta Orthop Scand Suppl. 1964;64:1-75.

2. The case for the specialty of medical angiology. European working group on medical angiology. Int Angiol. 1991;10:199-201.

3. Seligman B. Proposed training requirements for medical angiology fellows. European working group on medical angiology. Int Angiol. 1993;12:323-5.

4. Bauer G. Rationale and results of popliteal vein division. Angiology. 1955;6:169-89

5. Boyd AM, Catchpole BN, Jepson RP, Rose SS. Major venous ligation in the treatment of postphlebitic sequelae. Lancet [Internet]. 1953;262(6777):113-6. Available from: https://www.sciencedirect.com/science/article/abs/pii/ S0140673653900555.

6. Seligman B. Chronic venous insufficiency. Angiology. 1956;7:427-31.
7. Seligman B. The surgical approach to varicose veins. Angiology 1963;14:14-6.

8. Wesener G. Theraoy of varicose ukcer and concomitant symptoms of chronic venous inufficiency (eczema, dermoepidermitis, mycoses etc.). Rev Ther. 1969;26:226-32.

9. Kaufmann R. Phlebology--current therapeutic aspects from de dermatologic viewpoint. Z Hautkr. 1988;63:577-84.

10. Wiedmann A. The varicose sypmtom complex. Report on the literature of 1965. Zentralbl Phlebol. 1965;7:140-58.

11. Gundersen J. Lower limb bandage. Nord Med. 1965;75:1129-32.

12. Wiedmann A. The varicose sypmtom complex. Report of the literature of 1966. Zentralbl Phlebol. 1969;8:247-70.

13. Duenas FC. Dermatologic and general consequences of venous and lymphatic ectasia of the lower extremities: Remedial methods. Maroc Med. 1969;49:550-5

14. Fontaine R. Factors of chronicity in leg ulers of venous origin. Bull Soc Franc Dermatol Syphilipraphie. 1971;79:52-60.

15. Dale W. The swollen leg. Curr Probl Surg. 1973;1973:1-66.

16. Martinet J. Diagnosis of ulcers of varicose or postphlebitic origin. Rev Pract. 1975;25:975-87.

17. Schoevaerdts J. Physical treatment of venous edema. Physiopathological review. Phlebologie. 1989;43:51-4.

18. Duque MI, Yosipovitch G, Yiong HC, Smith R, Levy P. Itch, pain, and burning sensation are common symptoms in mild to moderate chronic venous insufficiency with an impact on quality of life. J Am Acad Dermatol. 2005;53:503-7.

19. Marston WA. Evaluation of varicose veins: What do the clinical signs and symptoms reveal about the underlying disease and need for intervention? Semin Vasc Surg. 2010;23:78-84.

20. Criqui M, Jamosmos M, Fronek A, Denenberg J, Langer R, Bergan J et al. Chronic venous disease in an ethnically diverse population: The San Diego population study. Am J Epidemiol. 2015;158:448-56.

21. Pappas PJ, Lakhanpal S, Nguyen KQ, Vanjara R. The center for vein restoration study on presenting symptoms, treatment modalities, and outcomes in medicare-eligible patients with chronic venous disorders. $J$ Vasc Surg Venous Lymphat Disord. 2018:6:13-24.

22. Łastowiecka-Moras E. Standing and sitting postures at work and symptoms of venous insufficiency-results from questionnaires and a Doppler ultrasound study. Int J Occup Saf Ergon. 2020;2020:1-17.

23. Ruckley CV, Evans CJ, Allan PL, Lee AJ, Fowkes FG. Chronic venous insufficiency: Clinical and duplex correlations. The Edinburgh vein study of venous disorders in the general population. J Vasc Surg. 2002;36:520-5.

24. Chiesa R, Marone EM, Limoni C, Volonté M, Schaefer E, Petrini O. Chronic venous insufficiency in Italy: The 24-cities cohort study. Eur J Vasc Endovasc Surg. 2005;30:422-9.

25. Branisteanu DE, Feodor T, Baila S, Mitea IA, Vittos O. Impact of chronic venous disease on quality of life: Results of vein alarm study. Exp Ther Med. 2019;17:1091-6.

26. Radak DJ, Vlajinac HD, Marinković JM, Maksimović MŽ, Maksimović ŽV. Quality of life in chronic venous disease patients measured by short chronic venous disease quality of life questionnaire (CIVIQ-14) in serbia. J Vasc Surg. 2013;58:1006-13.

27. McLafferty RB, Passman MA, Caprini JA, Rooke TW, Markwell SA, Lohr JM, et al. Increasing awareness about venous disease: The American venous forum expands the national venous screening program. $J$ Vasc Surg. 2008;48:394-9.

28. Andreozzi GM, Cordova R, Scomparin MA, Martini R, D'Eri A, Andreozzi $F$, et al. Effects of elastic stocking on quality of life of patients with chronic venous insufficiency. An Italian pilot study on Triveneto Region. Int Angiol. 2005;24(4):325-9.

29. Launois R, Reboul-Marty J, Henry B. Construction and validation of a quality of life questionnaire in Chronic Lower Limb Venous Insufficiency (CIVIQ). Qual Life Res. 1996;5(6):539-54.

30. Launois R, Reboul-Marty J, Henry B. Construction and validation of a quality of life questionnaire in chronic lower limb venous insufficiency (CIVIQ). Qual Life Res. 1996;5:539-54.

31. Mosti G, Partsch H. Improvement of venous pumping function by double progressive compression stockings: Higher pressure over the calf is more important than a graduated pressure profile. Eur J Vasc Endovasc Surg. 2014;47:545-9.

32. Mosti G, Mattaliano V, Partsch $\mathrm{H}$. Inelastic compression increases venous ejection fraction more than elastic bandages in patients with superficial venous reflux. Phlebology. 2008;23:287-94.

33. Vicaretti M. Compression therapy for venous disease. Aust Prescr. 2010;33:186-90.

34. Back TL, Padberg FT, Araki CT, Thompson PN, Hobson RW. Limited range of motion is a significant factor in venous ulceration. J Vasc Surg. 1995;22:519-23.

35. Dix PF, Brooke R, McCollum CN. Venous disease is associated with an impaired range of ankle movement. Eur J Vasc Endovasc Surg. 2003;25(6):556-61.

36. Pollack BA, Taylor BE, Myers TT, Wood EH. The effect of exercise and body position on the venous pressure at the ankle in patients having venous valvular defects. J Clin Invest. 1948;559-63. 
37. Pollack R, Wood $E$. Venous pressure in the saphenous vein at the ankle in man during exercise and changes in posture. J Appl Physiol. 1949;1:649-62.

38. Nieto-Zepeda DR, Flores-Aguilar SR, Carbajal-Robles V, Quintana-Aceves A, Sierra-Juárez MÁ, Santillán-Aguayo E. Resultados de la instauración de un programa de enseñanza y autocuidado en la cicatrización de úlceras venosas crónicas. Estudio de cohorte retrospectiva. Rev Mex Angiol. 2021;49(1):16-23.

39. Simon EB. Leg edema assessment and management. MEDSURG Nurs. 2014;23:44-53.

40. Ely JW, Osheroff JA, Chambliss ML, Ebell MH. Approach to leg edema of unclear etiology. J Am Board Fam Med. 2006;19:148-60.

41. Aldrete JA, Da Silva JM. Leg edema from intrathecal opiate infusions. Eur J Pain. 2000:4:361-5

42. Napier N, Shortt C, Eustace S. Muscle edema: Classification, mechanis$\mathrm{ms}$, and interpretation. Semin Musculoskelet Radiol. 2006;10:258-67.

43. Husmann MJ, Amann-vesti BR, Franzeck UK. Postural effects on interstitial fluid pressure in humans. J Vasc Res. 2006;43:321-6.

44. Partsch $\mathrm{B}$, Partsch $\mathrm{H}$. Calf compression pressure required to achieve venous closure from supine to standing positions. J Vasc Surg. 2005;42(2):734-8.

45. Bergan J, Jolla L. Molecular mechanisms in chronic venous insufficiency. Ann Vasc Surg. 2007;21(3):260-6.

46. Coleridge-Smith P. Inappropriate leukocyte activation in Venous Disease In: Bergan JJ, editor. The Vein Book [Internet]. 1st ed. Oxford, UK: Elsevier; 2007. p. 57-65. Available from: https://www.sciencedirect.com/ book/9780123695154/the-vein-book.

47. Hinghofer-Szalkay H. Gravity, the hydrostatic indifference concept and the cardiovascular system. Eur J Appl Physiol. 2011;111(2):163-74.

48. Ständer S, Weisshaar E, Mettang T, Szepietowski JC, Carstens E Ikoma $A$, et al. Clinical classification of itch: A position paper of the international forum for the study of itch. Acta Derm Venereol. 2007;87:291-4

49. Warlich B, Fritz F, Osada N, Bruland P, Stumpf A, Schneider G, et al Health-related quality of life in chronic pruritus: an analysis related to disease etiology, clinical skin conditions and itch intensity. Dermatology. 2015;231:253-9.

50. Paul J, Pieper B, Templin T. Itch: association with chronic venous disease, pain and quality of life. J Wound Ostomy Cont Nurs. 2011;38:46-54.

51. Zikel OM, Davis DH, Auger RG, Cherry KJ. Venous varix causing median neuropathy: Case illustration. J Neurosurg. 1997;87:130.

52. Levin LA, Danesh-Meyer H V. Hypothesis: A venous etiology for nonarteritic anterior ischemic optic neuropathy. Arch Ophthalmol. 2008;126:1582-5.
53. Reinhardt $F$, Wetzel $T$, Vetten $S$, Radespiel-Tröger M, Hilz MJ, Heuss $D$, et al. Peripheral neuropathy in chronic venous insufficiency. Muscle and Nerve. 2000;23:883-7.

54. Yim E, Vivas A, Maderal A, Kirsner R. Neuropathy and ankle mobility abnormalities in patients with chronic venous disease. JAMA Dermatol. 2014;150:380-4.

55. Keegan BR, Kamino H, Fangman W, Shin HT, Orlow SJ, Schaffer JV. Pediatric blaschkitis: expanding the spectrum of childhood acquired Blaschko-linear dermatoses. Pediatr Dermatol. 2007;24:621-7.

56. Young M, Boulton A, Macleod A, Williams D, Sonksen P. A multicentre study of the prevalence of diabetic peripheral neuropathy in the United Kingdom hospital clinic population. Diabetologia. 1993;36:150-4

57. Mold JW, Vesely SK, Keyl BA, Schenk JB, Roberts M. The prevalence, predictors, and consequences of peripheral sensory neuropathy in older patients. J Am Board Fam Pract. 2004;17:309-18.

58. Deyo R, Weinstein J. Low back pain. N Engl J Med. 2003;344:307-49.

59. Taimela S, Kujala UM, Salminen JJ, Viljanen T. The prevalence of low back pain among children and adolescents: A nationwide, cohort-based questionnaire survey in Finland. Spine (Phila Pa 1976). 1997;22:1132-6.

60. Casey E. Natural history of radiculopathy. Phys Med Rehabil Clin N Am. 2011;22:1-5

61. Tarulli AW, Raynor EM. Lumbosacral radiculopathy. Neurol Clin. 2007;25:387-405.

62. Modic MT, Obuchowski NA, Ross JS, Brant-Zawadzki MN, Grooff PN, Mazanec DJ, et al. Acute low back pain and radiculopathy: MR imaging findings and their prognostic role and effect on outcome. Radiology. 2005;237:597-604

63. Shiri R, Solovieva S, Husgafvel-Pursiainen K, Taimela S, Saarikoski LA Huupponen R, et al. The association between obesity and the prevalence of low back pain in young adults: The cardiovascular risk in young finns study. Am J Epidemiol. 2008;167:1110-9.

64. Knutson GA. Anatomic and functional leg-length inequality: A review and recommendation for clinical decision-making. Part I, anatomic leg-length inequality: Prevalence, magnitude, effects and clinical significance. Chiropr Osteopat. 2005:13:1-10.

65. Odel HM, Grace M, Roth GM, Keating FR. Autonomic neuropathy simulating the effects of sympathectomy as a complication of diabetes mellitus. Diabetes. 1955;4:92-8.

66. Rowland LP, Defendini R, Sherman W, Hirano A, Olarte M, Latov N, et al. Macroglobulinemia with peripheral neuropathy simulating motor neuron disease. 1981;11:21-4.

67. Kyroussis D, Polkey MI, Mills G, Hughes P, Moxham J, Green M. Cough simulated by rapid rate magnetic stimulation of the thoracic nerve roots. Thorax. 1997;52 Suppl 6:1696-9. 